\title{
Muscular pH of the rabbit
}

\author{
A Blasco *, M Piles \\ Departamento de Ciencia Animal, Universidad Politécnica de Valencia, \\ Camino de Vera, 14 Valencia 46020, Spain
}

(Received 9 June 1989; accepted 9 March 1990)

\begin{abstract}
Summary - Muscular $\mathrm{pH}$ of $\mathrm{L}$ dorsi and $B$ femoris was measured on 215 rabbit carcasses of 2 genetically different lines. There were some differences between lines in final $\mathrm{pH}-24 \mathrm{~h}$ after slaughter - and in drop in $\mathrm{pH}$ (between 15-20 $\mathrm{min}$ and $24 \mathrm{~h}$ post mortem). Final pHs were 5.71 and 5.66 ( $L$ dorsi) and 5.82 and 5.77 (B femoris); drop in pH was 1.00 and 1.05 ( $L$ dorsi), and 0.77 and 0.83 (B femoris). Carcass weight was not correlated with $\mathrm{pH}$ measurements.
\end{abstract}

muscular pH / rabbits / meat quality

Résumé - pH des muscles chez le lapin. L'évolution post mortem du $p H$ des muscles $L$ dorsi et $\mathrm{B}$ femoris est étudiée chez 215 lapins de 2 types génétiques. Les pH ultimes moyens (24 h post mortem) des 2 souches sont, respectivement, de 5,71 et 5,66 ( $\mathrm{L}$ dorsi), de 5,82 et 5,77 (B femoris). Les chutes de $\mathrm{pH}$ correspondantes (entre 15-20 min et $24 \mathrm{~h}$ post mortem) sont de 1,00 and 1,05 (L dorsi), de 0,77 et 0,83 (B femoris). Intra-souche, le poids de la carcasse n'est corrélé, ni avec le $p H$ ultime, ni avec la chute de $\mathrm{pH}$.

pH musculaire / lapin / qualité de viande

\section{INTRODUCTION}

Meat quality depends on a large number of factors often related with muscular $\mathrm{pH}$ (Lawrie, 1985). However, few studies have been made on the $\mathrm{pH}$ of rabbit carcasses. Differences among rabbit strains with a different adult size - and, consequently, at a different degree of maturity - have been found in $\mathrm{L}$ dorsi muscle (Ouhayoun, 1978). Ouhayoun and Delmas (1988) have also found differences between muscles in a strain, depending on the type of metabolism of the muscle. The objective of the present paper is to analyze the muscular $\mathrm{pH}$ of 2 muscles, on 2 genetically different strains of rabbits with the same adult size.

\section{MATERIALS AND METHODS}

215 rabbit carcasses of 2 rabbit strains (A and V) were measured. Line $A$ has a New Zealand origin and line $\mathrm{V}$ a synthetic line formed by blending 2 commercial hybrids whose genetic origin includes several breeds, with a main component being Californian. Both lines are now selected by litter size.

The rabbits were weaned at an age which varied between 27 and $29 \mathrm{~d}$, as weaning takes place on a fixed day. After weaning, they are placed in boxes -density 8 rabbits per box for $42 \mathrm{~d}$, and fed with a commercial granulated

\footnotetext{
* Correspondence and reprints
} 
food. The animals were slaughtered at an age which varied from 69-71 d. The rabbits were fed until slaughter. The slaughter house was close to the farm, and therefore the animals did not suffer the stress of transport. Two $h$ after slaughter, the carcasses were chilled at between 0 and $2^{\circ}$ for $22 \mathrm{~h}$.

The carcasses were weighed after slaughter and $24 \mathrm{~h}$ later, the accuracy of the scale being $10 \mathrm{~g}$. Muscular pHs of Longissimus dorsi - at the level of the 7th lumbar vertebra, right side and Biceps femoris were measured between 15 and $20 \mathrm{~min}$ after slaughter and $24 \mathrm{~h}$ later. A digital $\mathrm{pH}$-meter with an accuracy of 0.01 units of $\mathrm{pH}$ and a penetration electrode with a diameter of $3 \mathrm{~mm}$ were used. Males and females were chosen at random.

To test differences between strains and calculate descriptive parameters and correlations the BMDP statistical package was used (Dixon, 1983).

The following traits were analysed:

CWO: Carcass weight after slaughter;

CW24: Carcass weight $24 \mathrm{~h}$ after slaughter;

pHLO: $\mathrm{pH}$ of $L$ dorsi 15-20 min after slaughter;

pHL24: $\mathrm{pH}$ of $L$ dorsi $24 \mathrm{~h}$ after slaughter;
dpHL: absolute drop in $\mathrm{pH}$ of $\mathrm{L}$ dorsi (pHLOpHL24);

dpHL $p H L O$ : relative drop in $\mathrm{pH}$ of $\mathrm{L}$ dorsi;

$\rho H B O: \mathrm{pH}$ of $\mathrm{B}$ femoris $15-20 \mathrm{~min}$ after slaughter;

pHB24: $\mathrm{pH}$ of $\mathrm{B}$ femoris $24 \mathrm{~h}$ after slaughter; dpHB: absolute drop in $\mathrm{pH}$ of $\mathrm{B}$ femoris ( $\mathrm{pHBO}$ pHB24);

$d p H B / p H B O$ : relative drop in $\mathrm{pH}$ of $\mathrm{B}$ femoris.

\section{RESULTS}

Table I shows the means, standard deviations and variation coefficients of carcass weights and $\mathrm{pHs}$. $\mathrm{pH}$ values are slightly lower than the values of Ouhayoun (1978), but similar to those of Ouhayoun and Delmas (1988). As stress before slaughter probably varies, it is not surprising to find that certain authors have noted some differences in $\mathrm{pH}$. The $\mathrm{pH} 24$ of $\mathrm{L}$ dorsi is lower than the $\mathrm{pH} 24$ of the $\mathrm{B}$ femoris due to the different metabolism of the muscles, $\mathrm{B}$ femoris being more oxidative. However, the initial $\mathrm{pH}$ is higher in $\mathrm{L}$ dorsi, which im-

Table I. Means with their standard errors (SE), standard deviations (SD), and coefficient of variation (CV) of carcass weight and $\mathrm{pH}$ traits of 2 rabbit lines (Characters in the text).

\begin{tabular}{|c|c|c|c|c|c|c|c|c|c|}
\hline \multirow[b]{2}{*}{ Trait } & \multicolumn{4}{|c|}{ Line $V$} & \multicolumn{4}{|c|}{ Line $A$} & \multirow[b]{2}{*}{$\mathrm{Sig}$} \\
\hline & Mean & $S E$ & $S D$ & $c V$ & Mean & $S E$ & $S D$ & $\mathrm{CV}$ & \\
\hline CWO & 1224 & 12 & 121 & 0.10 & 1257 & 12 & 119 & 0.09 & NS \\
\hline CW24 & 1206 & 12 & 120 & 0.10 & 1238 & 12 & 116 & 0.09 & NS \\
\hline pHLO & 6.72 & 0.008 & 0.08 & 0.01 & 6.72 & 0.009 & 0.09 & 0.01 & NS \\
\hline pHL24 & 5.66 & 0.007 & 0.06 & 0.01 & 5.71 & 0.007 & 0.06 & 0.01 & * \\
\hline dpHL & 1.05 & 0.012 & 0.11 & 0.10 & 1.00 & 0.013 & 0.12 & 0.12 & * \\
\hline $\mathrm{dpHL/pHLO}$ & 0.15 & 0.001 & 0.01 & 0.09 & 0.14 & 0.001 & 0.02 & 0.11 & * \\
\hline pHBO & 6.60 & 0.011 & 0.11 & 0.01 & 6.60 & 0.014 & 0.13 & 0.02 & NS \\
\hline pHB24 & 5.77 & 0.007 & 0.06 & 0.01 & 5.82 & 0.007 & 0.06 & 0.01 & * \\
\hline $\mathrm{dpHB}$ & 0.83 & 0.014 & 0.14 & 0.17 & 0.77 & 0.016 & 0.15 & 0.20 & * \\
\hline $\mathrm{dpHB} / \mathrm{pHBO}$ & 0.13 & 0.002 & 0.02 & 0.15 & 0.12 & 0.002 & 0.02 & 0.18 & * \\
\hline
\end{tabular}

NS: No significative differences between lines;

*: Significative differences $(P<0.05)$ between lines. 
plies a higher absolute drop in $\mathrm{pH}$. The drop in $\mathrm{pH}$ relative to the initial $\mathrm{pH}$ is also higher in $\mathrm{L}$ dorsi. There are some differences between lines in final $\mathrm{pHs}$ and drop in $\mathrm{pH}$, line $\mathrm{A}$ having higher final $\mathrm{pH}$ in both muscles and drops in lower $\mathrm{pH}$. There were no differences between lines in initial pHs.

Table II shows the correlations between traits. The correlations between carcass weights and $\mathrm{pHs}$ are proximal to 0 in all cases and lines. There are no relevant correlations between initial and final $\mathrm{pH}$, but there is a relatively high correlation between drop in $\mathrm{pH}$ and both initial and final $\mathrm{pH}$; this is probably an artificial correlation, because both are components of the drop in $\mathrm{pH}$. There is some correlation within lines between muscular $\mathrm{pH}$ of $\mathrm{L}$ dorsi and $\mathrm{B}$ femoris.

\section{DISCUSSION}

The coefficients of variation of the $\mathrm{pHs}$ are small, but as the $\mathrm{pH}$ of the carcass has a reduced range of variation, standard deviation and coefficient of variation are not reliable indicators of the real variation in $\mathrm{pH}$, as far as the quality of the meat is concerned. A better indicator would be the variation co-efficient of the $\mathrm{pH}$ falls, which is more similar to the variation coefficient of other productive traits.

Quality of meat has been associated with PSE (pale, soft and exudative muscle) related to a drop in $\mathrm{pH}$. In pigs, PSE is also associated with the Porcine Stress Syndrome (PSS), depending on a single gene (Webb et al, 1985) which apparently is not present in rabbit populations. However, recent studies in pigs place more importance on the final $\mathrm{pH}$ than to the drop in $\mathrm{pH}$ to for evaluating meat quality, independently of whether PSS is involved or not (Sellier et al, 1988). In our case, the differences between the strains $A$ and $V$ are smaller than the differences found between pig breeds, but line $\mathrm{V}$ showed lower final $\mathrm{pH}$ in both muscles, which suggests the existence of

Table II. Correlation coefficients between carcass traits and pHs. Line A above the diagonal, line $\mathrm{V}$ below the diagonal (Characters in the text).

\begin{tabular}{|c|c|c|c|c|c|c|c|c|c|c|}
\hline & cWo & CW24 & pHLO & pHL24 & $d p H L$ & $\begin{array}{l}d p H L / \\
p H L O\end{array}$ & $\mathrm{pHBO}$ & pHB24 & $d p H B$ & $\begin{array}{r}d p H B / \\
d p H B O\end{array}$ \\
\hline cWo & * & 1.00 & -0.18 & 0.15 & -0.21 & -0.21 & -0.04 & 0.17 & -0.10 & -0.11 \\
\hline CW24 & 1.00 & * & -0.18 & 0.13 & -0.20 & -0.20 & -0.03 & 0.17 & -0.10 & -0.11 \\
\hline pHLO & 0.12 & 0.12 & $\star$ & -0.27 & 0.87 & 0.84 & 0.38 & -0.15 & 0.39 & 0.40 \\
\hline pHL24 & 0.15 & 0.14 & -0.18 & * & -0.71 & -0.75 & -0.24 & 0.42 & -0.39 & -0.41 \\
\hline $\mathrm{dpHL}$ & -0.00 & 0.01 & 0.83 & -0.70 & * & 1.00 & 0.41 & -0.32 & 0.49 & 0.50 \\
\hline $\mathrm{dpHL} / \mathrm{pHLO}$ & -0.01 & -0.00 & 0.78 & -0.75 & 1.00 & * & 0.40 & -0.34 & 0.49 & 0.51 \\
\hline $\mathrm{pHBO}$ & -0.01 & 0.00 & 0.47 & -0.31 & 0.52 & 0.51 & * & -0.10 & 0.90 & 0.88 \\
\hline pHB24 & 0.07 & 0.06 & 0.06 & 0.57 & -0.28 & -0.32 & -0.16 & * & -0.51 & -0.55 \\
\hline $\mathrm{dpHB}$ & -0.04 & -0.02 & 0.35 & -0.52 & 0.55 & 0.57 & 0.88 & -0.61 & • & 1.00 \\
\hline $\mathrm{dpHB} / \mathrm{pHBO}$ & -0.04 & -0.03 & 0.33 & -0.54 & 0.55 & 0.57 & 0.86 & -0.64 & 1.00 & \\
\hline
\end{tabular}

Values under 0.19 are not significantly different from 0. 
some genetic variation for this trait. Relative drop in $\mathrm{pH}$ corrects some kind of scale effect due to different initial pHs - for example, having the same absolute fall, implies a different final $\mathrm{pH}$. The differences between lines for this trait are somewhat irrelevant.

The independence of $\mathrm{pH}$ and carcass weight would suggest that carcass weight does not affect meat quality - as far as meat quality is related to $\mathrm{pH}-$ within the range of variation of this experiment, corresponding to the Spanish carcass market.

The observed correlation between $L$ dorsi and $\mathrm{B}$ femoris pHs suggest that there are some differences in metabolism among animals.

\section{REFERENCES}

Dixon J (1983) BMDP Statistical Software. Mc Graw-Hill, Berkeley, $734 p$

Lawrie RA (1985) Meat Sci. Pergamon Press, Oxford, $451 \mathrm{p}$

Ouhayoun J (1978) Étude comparative de races de lapins differant par le poids adulte. Thesis. Univ des Sciences et Techniques du Languedoc, $72 p$

Ouhayoun J, Delmas D (1988) Meat Quality of Rabbit. I. Differences between Muscles in Post-Mortem pH. 4th World Rabbit Congress. Budapest 10-14 October 1988, 2, 412-418

Sellier $P$, Mejenes-Quijano A, Marinova $P$, Talmant $A$, Jacquet $B$, Monin $G$ (1988) Meat quality as influenced by halothane sensitivity and ultimate $\mathrm{pH}$ in three porcine breeds. Livest Prod Sci 18, 171-186

Webb AJ, Southwood OI, Simpson SP, Garden AE (1985) Stress Susceptibility and Meat Quality in Pigs. EAAP Publ No 33, 9-32 